\title{
The determinants of services FDI location in the UK regions
}

Dr. Mark Cook, Reader in International Business, The University of Wolverhampton, Business School, Wulfruna Street, Wolverhampton, WV1 1AD, UK.

E-mail: Mark.Cook@wlv.ac.uk

Dr. Grahame Fallon, Senior Lecturer in International Business, Brunel University, Kingston Lane, Uxbridge, Middlesex UB8 3PH, UK.

E-mail: Grahame.Fallon@brunel.ac.uk

\begin{abstract}
This paper contributes to scholarly knowledge and understanding of the way in which economic conditions and government policy affect foreign direct investment (FDI) location in the United Kingdom (UK) regions. It does so by exploring their impact on inbound services FDI location in a sample of one of the UK's core (South East England) and four non-core (West Midlands; Wales; Scotland and the North West) regions. Use is made of multiple regression techniques to analyse a set of official, longitudinal data gathered for the period from 1980 to 2015 as a means to this end. The findings offer new insights into the relative influence of the search for markets, efficiencies and strategic assets and government policy over the location of services FDI in all five regions. The resultant implications for future inward investment policy development after the UK leaves the EU are also considered, including the potential benefits of increasing policy variations from region to region.
\end{abstract}

\section{Key words}

Inbound FDI location determinants, core and non-core regions, multiple regression analysis, economic and government policy influences, implications for future government policy, United Kingdom 


\section{Bibliographic Notes}

Mark Cook is a Reader in International Business at the University of Wolverhampton. $\mathrm{He}$ has published extensively in the area of regional UK FDI and in the area of FDI in football. His publications also include books on International Business, Managerial Economics and Supply-side Economics. He is currently working in the area of R\&D FDI and FDI into SubSaharan Africa.

Dr. Grahame Fallon is a Senior Lecturer in International Business at the Brunel Business School (BBS). His research interests lie at the intersection of international business, entrepreneurship, political economy and institutional theory. His work focuses primarily on the determinants and impact of foreign direct investment and SME development in the UK and post-communist country contexts. He has published and reviewed papers in a range of journals, including Regional Studies, the Tijdschrift voor Economische en Sociale Geografie, Journal of Small Business and Enterprise Development, the Journal of East-West Business, Strategic Change and the Canadian Journal of Administrative Science.

\section{Introduction}

There has been much research (for example, Hill and Munday, 1992, 1995; Dunning 1998, 2005; Driffield and Munday 2000; Chakrabarti 2003; Fallon and Cook 2010) into the determinants of inbound foreign direct investment (FDI) location into the manufacturing and services sectors, particularly in developed market economies such as the United Kingdom (UK). These papers provide valuable information on the strategic determinants and proximate motives underlying multinational enterprises' (MNEs') FDI location decisions. However, far less attention has been paid to the way in which economic conditions and government policy affect FDI location in more economically developed core and less developed non-core regions, together with the resultant implications for inward investment 
policy. This paper seeks to contribute to scholarly knowledge and understanding by filling this gap in the literature.

The determination of inbound, manufacturing and services FDI location is a topic of considerable importance to governmental policy-makers and scholars, owing to the influential role that FDI can play in the development of national and regional economies. The UK has performed exceptionally well in inward investment terms since 1980, with the result that it has become, and still remains the leader in FDI attraction to Europe (EY, 2017). Inbound FDI plays an important part in the UK economy, contributing 18 per cent of national employment, 25 per cent of gross wages, 30 per cent of its capital expenditure and 28 per cent of its gross value added in 2014 (ONS, 2017). It varies considerably from sector to sector, however, with services activities accounting for $73 \%$ of the UK's current FDI stock, compared to a smaller $20 \%$ in the case of manufacturing and the remaining $7 \%$ in the primary sector (Oxford Economics, 2014). Inbound FDI also differs markedly from region to region, with London and the Southeast continuing to outperform other UK regions in inbound FDI location terms (ONS 2016).

The UK's economic difficulties in the years from 2008-11 (following the global financial crisis and the resultant prolonged recession) had a significant impact on inward investment to the UK and its regions, reflected in a sustained reduction in FDI inflows to the manufacturing and services sectors (UNCTAD WIR, 2017). This trend was eventually reversed after three years, with the result that by 2015 , the UK as a whole achieved its highest number of FDI projects since the late nineteen nineties (EY, 2016). The long term 
attractiveness of the UK and its regions to FDI is now in doubt, however, owing to significant MNE concerns regarding future UK access to EU's Single Market and customs union following Brexit (EY, 2017). The ability of manufacturing and services FDI inflows to contribute to economic development in the UK regions is therefore subject to increased doubt. This is resulting in new challenges for governmental policymakers which provide an added contextual importance and currency for the current paper.

The paper seeks to provide new and valuable insights by examining the way in which economic conditions and government policy affects foreign direct investment (FDI) location in the United Kingdom (UK) regions. The next section provides a theoretical framework regarding the determinants of inbound FDI location, resulting in the generation of testable hypotheses. The following section briefly considers the contrasting IFDI performance of the UK regions, in both overall and services sector terms. We then go on to outline and explain the literature-based model of services FDI location that has been used for the econometric analysis of official, longitudinal data for the period from 1980 to 2015. The resultant findings are next presented, resulting in new insights into the relative influence of the search for markets, efficiencies and strategic assets and government policy over services FDI location in the five sample regions. The resultant implications for future inward investment policy development after the UK leaves the EU are finally considered, including the potential benefits of increasing policy variations from region to region.

\section{Theoretical Framework}

The FDI location decisions taken by MNEs are typically hierarchical in character (Devereux 
et al. 2001; Crozet et al. 2004). Strategic decision makers begin their location process by targeting an economic bloc (such as the EU), followed by a particular country within the bloc (such as the UK), before moving their focus to one of its core or non-core regions (Loewendahl, 2001a). Elements from all three stages of this spatial hierarchy shape MNEs' IFDI location decisions, in all sectors of the economy.

The strategic determinants and specific motives that drive the location of services sector FDI depend on the competitiveness of individual regions in terms of market conditions, productive efficiency, and the availability of strategic assets such as knowhow and technology (Dunning, 2006; Richelieu, 2008). These factors are influenced by the economic conditions that prevail at the EU, national and regional levels, as well as by governments' inward investment policy decisions (Liebscher et al. 2007; UKTI 2011a, 2011b). MNEs often respond to higher levels of economic development by locating relatively large amounts of inbound FDI in core regions (such as Southeast England) (Kottaridi, 2005; Dunning 2006; Pearce 2006; Rowthorn 2010). It can be challenging for governmental investment incentives to alter this pattern and to persuade inward investors to switch their thinking and planning to less economically developed non-core regions (Loewendahl 2001a, 2001b).

The determinants and proximate motives driving inbound services sector FDI location can be expected to vary between the core and non-core regions of the UK (UKTI 2011a, 2011b). The relative influence of EU, national and regional factors on inbound FDI location may also differ considerably from region to region. The importance of market, efficiency and strategic asset-seeking to FDI location may also alter over time, as economic development 
progresses (Dunning and Narula, 1996, 2004; Dunning 1998). We therefore hypothesise:

Hypothesis 1: There are significant differences between the strategic determinants and specific motives that attract services FDI inflows within and between the core and non-core regions of the UK.

Hypothesis 2: The relative influence of regional, national and EU factors on inbound FDI location varies systematically between the UK's core and non-core regions.

\section{Market-seeking FDI}

Market-seeking FDI is often the main determinant of inbound FDI location in the services sector for core and non-core regions alike (Driffield and Munday 2000; Loewendahl 2001a; Riedl, 2010). EU Single Market access, as well as the state of the UK's national market may be expected to influence the inflow of market seeking, services FDI into the UK's regions (Liebscher et al. 2007). This may be drawn more heavily to core regions owing to their higher population density and per capita income levels, their larger market size and better long-term growth prospects (Dunning 1981; Wheeler and Moody 1992; Billington, 1999). Their appeal to market-seeking, services sector IFDI may also be accentuated, by relatively well developed transport and communications infrastructures (Yeung and Strange 2005) and by the greater ability to access and exploit market-related agglomeration economies that they may offer (Martin and Sanely, 1996). Market - seeking FDI may also be attracted into non-core regions where there is growing market size and potential (Fallon and Cook, 2010), a lower intensity of competition (Gorg and Ruane 2001; Henisz and Delios, 2001) and improved opportunities for market access and face to face contacts (Wren and Jones, 2012; Jones and Wren, 2016). 


\section{Efficiency-seeking FDI}

Both regional and national factors can be expected to impact on the commitment of efficiency-seeking IFDI to core and non-core regions alike (Liebscher et al. 2007). MNEs may also be driven to invest in the UK's regions by the desire to lower their operational costs through access to more abundant and cheaper inputs, such as capital and labour (Loewendahl 2001a; Dunning, 2006). The existence of an abundant labour supply, in addition to low costs, high levels of education, training and productivity and a low propensity to strike are all likely to attract efficiency seeking FDI inflows into both sectors and types of region (Schneider and Frey 1985; Hill and Munday 1992, 1995; Yeung and Strange 2005). On the other hand, relatively high labour costs and negative wage differentials are likely to deter services IFDI commitment, unless relatively high levels of labour productivity offset this effect (Billington, 1999; Ford and Strange 1999). The presence or absence of regional concentrations and local clusters of related and supporting industries are also likely to have a significant impact on services FDI location in both types of region (Porter 1998, 2000; Guimaraes et al., 2000; Shaver and Flyer 2000), as is the existence of a robust, regional small business sector (Dunning and Narula, 2004; Tavares and Young 2005).

\section{Strategic asset-seeking FDI}

The availability of strategic assets, such as science and technology can also be significant determinants of inbound FDI location in the services sector, and a particular attraction in the 
case of core regions (Dunning and Narula 2004). The existence of high regional levels of R\&D expenditure, internationally competitive, know-how-intensive clusters and highly skilled labour can draw more innovative services sector MNEs into such regions (Gorg and Ruane 2001; Hall, 2011). The promotion of cluster development, R\&D and labour skills training may therefore help to attract strategic asset-seeking FDI into core regions, although non-core regions will be considerably less likely to attract such inward investment, unless they are able to develop the technology and skills-related assets that more developed regions possess (Makino et al. 2005).

\section{Government policy}

Governments can also exercise substantial influence over the regional location of services sector FDI, in both core and non-core regions, through their FDI-related policy interventions (Loewendahl 2001a, 2001b; Tavares and Young 2005). It is likely that national government policies will have a larger impact on regional IFDI location by services sector MNEs, in England at least (UKTI 2011a, 2011b), owing to the far more limited powers and resources available to local government (Wilson and Game, 2011).

The same comment can be made, to a lesser degree regarding inward investment into the services sector in the 'Northern Powerhouse' and 'Midland Engine' regions of England (House of Commons, 2015), as well as the devolved government regions, including Scotland, Wales and Northern Ireland. Although the latter in particular have developed active inward investment strategies (Raines, 2000), none yet has the power to vary business taxation or exchange rates, which can be the most important policy influences on FDI 
location at the national and regional levels. In consequence, the most quantifiable government policy influences on the attraction of services sector FDI to the UK regions still originates in interventions that take place at the national level, which then apply to all UK regions alike (Lee and Min 2011; Ghinamo et al. 2010). Thus we hypothesise:

Hypothesis 3: Government FDI-related policies have a significant influence on the UK regional location of services sector FDI.

It may, nonetheless make sense for national government policies to vary between core and non-core regions, in order to maximise services FDI inflows. We therefore hypothesise:

Hypothesis 4: Government FDI-related policies should vary from region to region, in order to maximise services sector FDI inflows.

The UK government does, indeed vary the rate of regional financial assistance available to manufacturing as well as services sector inward investors from region to region across the $\mathrm{UK}$, in response to interregional differences in geography, economic development and attractiveness to inbound FDI (UKTI 2011a, 2011b).

\section{The inbound services FDI performance of the UK regions}

The five sample regions included in this paper reflect the economic divide between the UK's core (represented here by South East England) and non-core (exemplified by the West Midlands, wales, Scotland and the North West) (see Table 1).

[Table 1 near here] 
The (core) Southeast England region is larger in population and GVA terms than each of the other four (non-core) regions included in the study (ONS 2012), contributing to the UK's so-called 'North-South divide' (Kottaridi, 2005; Rowthorn 2010). Median full time earnings are relatively higher in the Southeast, boosting consumers' incomes and purchasing power, but also raising labour costs. The Southeast also possesses a relatively large labour force, high employment and low unemployment rate, a strong position in educational and workforce skills terms, and far higher levels of $\mathrm{R} \& \mathrm{D}$ expenditure than the non-core regions, although lower government expenditure on RPA is an offsetting factor. The services sector also makes a relatively larger contribution to GVA in the Southeast than for the sample noncore regions (Table 2).

[Table 2 near here]

There is currently a scholarly debate (Stone and Peck 1996; Tewdr-Jones and Phelps 2000; Mackay 2003; Fallon and Cook, 2010), regarding whether core UK regions such as the Southeast are losing their relative attractiveness to inbound FDI, although official statistics (ONS 1981-date) would appear to contradict this argument. The regional mix of inward investment shows no consistent pattern over the last two years (2015-16). Published data from 2015 (EY, 2016) suggest that the attraction of IFDI was becoming less regionally skewed, helping the UK to begin reducing the North-South divide and rebalancing its economy. Nearly $90 \%$ of the UK's total inward investment growth came from none-core regions, with the North West, Scotland and the West Midlands performing particularly well 
in new project terms. The North West led the way with an increase in projects of $118 \%$, Yorkshire achieved 66\%, Scotland 51\% and the West Midlands 46\%, whilst the South East fared poorly, recording a $22 \%$ year on year decline.

The position changed markedly in 2015 (EY, 2017) however, when the South East achieved an $11 \%$ increase (helped by increases in project volumes in the business and financial services sectors). Although West Midlands FDI project numbers rose again, by 21\%, Scotland's increase was relatively small, at 3\%, while both Wales and the North West recorded decreases, of $44 \%$ and $11 \%$ respectively. This would suggest that the historical patterns of IFDI distribution were re-emerging, with strong, core regions once again outperforming their less developed, non-core counterparts in inward investment terms (See Table 3).

[Table 3 near here]

\section{Research methodology}

The basic model underlying the multiple regression analysis (MRA) underlying this paper was developed from the FDI location literature, making use of a framework developed by Hill and Munday (1992, 1995); Stone and Peck (1996); Billington (1999) and Jones and Wren (2004). Tables 4-7 detail the nature, provenance and unit of analysis of the explanatory variables used in the MRA to estimate the strategic determinants and specific motives that attract inbound services FDI inflows into the sample UK core and non-core regions. 
Single equation, multivariate, regression models were developed for each sample region, using an estimation procedure based on a Poisson-type model, with flows of inbound FDI (proxied by the number of new projects per year) being used as the dependent variable in each case. The methodology employed throughout was to regress a range of potential explanatory variables (reflecting differing specific motives for inbound FDI location at the regional, national and EU levels) on this dependent variable until 'best fit' models were obtained for services FDI inflows into each of the sample regions. Five separate best fit equations are estimated; one for each region representing services FDI location:

Services FDI in a region $=\mathrm{B} 0+\mathrm{B} 1$ Markets (regional, national and EU) $+\mathrm{B} 2$

Efficiency (regional and national) + B3 Strategic Assets (regional and national) + B4 Government policy (regional and national).

\section{Choice of independent variables}

The choice of explanatory variables for the MRAs was governed by theoretical issues and by data availability. A range of variables reflecting the specific motives for services FDI location linked to each of the strategic determinants was considered in turn for each sample region, following a procedure set out by Judd and McClelland (1989). A hierarchical approach was followed for each region, starting with EU-level and then national explanatory variables, before moving onto regional level variables. In the case of market-seeking FDI, for example, a variety of alternative, motive-related variables, including measures of market size, infrastructure quality and existing stocks of FDI at the regional, national and EU levels were consecutively introduced, being discarded where they lacked explanatory power. 
Tables 4-7 list the explanatory variables used in our MRAs.

[Tables 4-7 near here].

A stepwise approach to determine the predictors in each regional model was not considered to be appropriate (see Wilkinson and Dallal, 1981; Judd and McClelland 1989), given the limited degrees of freedom in the model. Attempts were made to control for zero inflation by including independent variables expressed in real terms in the MRAs, where appropriate.

High levels of correlation were anticipated between the different motives for market, efficiency, and strategic asset-seeking FDI and government policy influence in each of the sample regions. Efforts were made, therefore, to estimate the degree of correlation in each case by using a correlation matrix. Where multicollinearity was found to exist between explanatory variables, only one of the inter-related variables was used in any equation at any one time. The worst performing variable in any pair was excluded after being tried separately in each of the regression equations.

It was feared that limiting the range of independent variables to one for each strategic determinant of FDI per region could lead to omitted variable bias, if the 'true' functional form of an equation was unknown (Swamy et al., 2003). In order to mitigate this problem, the equations were developed to mirror the theoretical underpinnings of the determinants of 
services FDI location. Moreover, each of the explanatory variables included in the regional equations was used to proxy for others, thereby trading off reduced multicollinearity for some omitted variable bias.

A number of theoretical and practical procedures were used in order to identify and remove heteroscedasticity, linked to the omission of variables, non-linearities in the functional form, or aggregation. Different functional forms of each regional equation were tried, and the Levene and the Mackinnon and White tests were used to test for this problem. In none of these tests however, could heteroscedasticity be identified.

A weighted least square approach was rejected, reflecting Greene's (1990, p. 470) view that 'by using the wrong set of weights this in itself poses further problems, in that the weighted least squares estimator is inefficient. If the form of the heteroscedasticity is known but involves unknown parameters, it remains uncertain whether GLS corrections are better than OLS. Asymptotically, the comparison is clear, but in small or moderate-sized samples [which we have here], the additional variation incorporated by the estimated variance parameters may offset the gains to GLS'. It was also found that taking logs of the various equations failed to alter the significance or specification of any of the equations.

To test for regime changes associated with the introduction of the English RDAs (in 1999), a dummy variable (see Table 7) was included in each of the regional services FDI equations, taking a value of zero before 1999 and one thereafter up to 2010 when the RDAs were disbanded and replaced by Local Enterprise Partnerships (LEPs). Although the coefficient of 
this variable proved to be positive as expected, it was never significant. A second dummy variable, D2 was included to take into account the development of the LEPs (as shown in Table7). A third was added to take into account the development of the devolved national assemblies, taking the value zero before 1999 and one thereafter. Finally, a fourth dummy variable was included to take into account the financial crisis (details are shown in Table 7). Given the relative size of the data set for each region, multiple dummy variables were not included simultaneously as this would create degrees of freedom problems.

\section{Choice of dependent variable}

FDI 'new project successes' were used to proxy inflows of services FDI to each of the sample regions between 1980 and 2005, making use of data from ONS (1981-20016; following Hill and Munday 1992; Billington 1999). The ONS data set was considered the most appropriate on accuracy and 'reliability' grounds (ONS 2016), and this judgement was reinforced by the fact that this source was also used to provide UK national and regional FDI data for the EU and OECD. Data from other sources such as Ernst and Young (based on Oxford Intelligence data) were not employed, since their collection only began in 1997, thus their use would have restricted the length of the time series employed in the econometric analysis. Their FDI data source (fDi Intelligence 2015) also has a strong focus on greenfield investment projects whereas UK regional FDI also encompasses mergers and acquisitions, joint ventures and strategic alliances (as reflected in the preferred ONS data set).

New project data may under-represent the numbers of projects undertaken in core regions 
such as Southeast England, where there may be little government or regional assistance available to support FDI or to encourage MNEs to notify it to government (Hill and Munday 1992; Billington 1999). They may also conflate new with expansionary investment (Stone and Peck 1996), and ignore the variation in the value (since inward investment is often concentrated in a small number of projects) and job intensity (often lower for larger than for smaller projects) of new FDI projects (Jones and Wren 2004).

One way of overcoming such problems could have been to measure inbound FDI in terms of new jobs created or capital intensity. The new jobs measure was rejected however, since it could have led to difficulties in distinguishing actual from expected jobs created, jobs safeguarded, and jobs lost or displaced through inbound FDI (Stone and Peck 1996; Fallon et al. 2011; Fallon and Cook 2012; Fallon and Cook 2013). Capital intensity was also rejected, due to the weakness of the correlation between jobs created and capital investment in FDI-related projects (Jones and Wren 2004) and between new projects and capital investment (Fallon et al. 2011; Fallon and Cook 2012; Cook and Fallon, 2016. New projects were therefore considered to be the best measure of FDI inflows at the regional level (following Hill and Munday 1992).

\section{Findings}

Table 8 summarises the multiple regression results for each sample region (making use of the variables listed in Tables 4-7).

[Table 8 near here] 
A Poisson analysis suggests that there are substantial variations in the strategic determinants and specific motives underlying services FDI location in each of our sample regions. Services FDI location is driven solely by regional motives in three regions (the Southeast, Wales and the Northwest) whilst in the other two regions, (the West Midlands and Scotland), the determinant of services FDI is driven by a combination of both regional and national factors. None of the EU-level measures used in this analysis play a significant part statistically, in determining services FDI in any of the five sample regions.

Taking each region separately, in the (core) Southeast region, service FDI inflows are determined significantly by REGGDPPCREAL, REGINON, REGCLUSTERS and REGAWCREAL, together with the dummy variable D3(signifying the positive and significant effect of the financial crisis on services FDI inflows). All the significant variables have the a priori expected signs. For the South east, service FDI inflows are mainly determined by a combination of market seeking and efficiency seeking factors together with the financial crisis dummy variable.

The results obtained for the West Midlands indicate that services FDI is driven by UKFOLLOW and REGFINREAL. Both have the expected positive signs. It is a combination of market seeking and government policy that influences the service FDI inflows to this region.

With regard to Wales, the three significant explanatory variables for services FDI inflows, 
REGCLUNEMP, REGFINREAL, and the financial crisis Dummy (which has the expected sign). The former two variables have unexpectedly negative signs. The negative sign for REGCLUNEMP suggests that FDI inflows rise as regional unemployment decreases. The former result can be explained by the connection between falling unemployment levels and the concomitant rise in demand can improve the financial well-being of the region, leading to an increase in market-seeking service FDI. The negative sign for REGFINREAL can be linked to the growing prosperity of the principality, reducing its dependency on financial regional assistance and this again acts as an attractiveness factor for services FDI. Official government statistics (Table 3) provide some support for this view, suggesting that Wales may have performed relatively well in increasing its attractiveness to services FDI in recent years, despite an apparent levelling off of regional assistance. Like the South East region, Wales was also significantly affected by the financial crisis. As one of the relatively weaker regions of the UK, it suffered significantly from the down turn of total and service sector FDI.

For services FDI inflows into Scotland, UKGDPPCREAL and REGWAGEINEQ are both significant, although the latter has an unexpectedly positive sign. One explanation could be that a rise in regional earnings relative to the national average is having the effect of raising consumer expenditure in the Scottish region, thereby helping to precipitate a rise in marketseeking inflows of services FDI. Furthermore, Scotland was the only region in our analysis where the dummy variable, linked to impact of devolved government, had a significant and positive impact on the inflow of services FDI. This was unlike Wales, where the variable was not significant. The moved to a devolved government has been linked with a 
weakening of the Welsh RDA brand whereas Scotland continued with its tried and tested familiar brand, (House of Commons, 2012). In this respect Scotland was able to build upon a tried and tested brand image and attract more services FDI than its Welsh cousin with its less familiar brand established by the Welsh Assembly Government (WAG), National Assembly for Wales (2014) and House of Commons welsh affairs Committee,(2012) .

Two statistically significant variables are found to explain services FDI inflow into the Northwest. REGPRODUCTI appears to be having the expected, positive impact on services FDI. REGBASICED has an unexpectedly negative sign, however, suggesting that a rising proportion of school leavers with GCSEs is negatively related to such FDI. This could be explained through the fact that by increasing GCSE attainment in the region may be linked to rising sixth form and higher education participation rates, but not to improved perceptions of regional workforce quality and skills on the part of services MNEs. They may instead believe that these trends will result in a regional shortage of lower skilled labour (a feature noted with the decline in UK and Scottish productivity levels (Guardian 2016, ONS 2016, Thomas and Gunson, 2017), with the result that services FDI may be deterred from investing directly in the region.

In terms of the determinants of service sector FDI inflows to these five regions, the results indicate not only differences between the drivers which in some regions are more regionally or nationally focused, but where regional factors predominate, there are also regional variations between the regional factors. Furthermore, government policy directly, irrespective of its other indirect effects on for example, employment and wages, has 
influenced the services FDI inflows into four of our regions.

\section{Conclusions}

The findings reported here extend the analysis of FDI location in the UK by exploring the determinants of inbound services FDI location within and between a number of the UK's core and non-core regions, together with the resultant implications for government policy. The findings are broadly consistent with those from existing, non-sectorally based studies (such as Fallon and Cook 2010) and sectoral studies (such as Fallon and Cook, 2013) in that the strategic determinants of regional inbound FDI location would appear to include the search for efficiency, markets and (to a lesser extent) strategic assets, together with government policy.

There appear to be statistically significant differences between the strategic determinants and specific motives that attract services FDI inflows to the UK's core and non-core regions (as suggested in Hypothesis 1). The findings provide evidence of inter-regional divergences in the relative influence of regional and national factors on the location of services FDI, although EU-level factors play no statistically significant part in driving FDI inflows into either sector of the sample regions. There is also no evidence of systematic variation in the relative influence of these factors between the UK's core and non-core regions. Hypothesis 2 must therefore be rejected.

\section{Policy implications}

Government FDI-related policies do appear, from this paper's findings, to have a significant 
influence on the UK regional location of inbound services FDI in the case of some regions at least (as suggested in Hypothesis 3). It can thus be argued that government FDI-related policies should be allowed to vary from region to region, if FDI inflows are to be maximised (reflecting the inter-regional differences in the determinants and motives for FDI location found in the MRAs). Hypothesis 4 should therefore be accepted. This move towards government FDI-related policies may lie behind the establishment of devolved government, the move toward regional/local mayors and the further development of regions such as the Northern Power House and/or Midlands Engine, where local players/regions can play a more active part in the needs of their region.

A successful outcome to the replacement of the Regional Development Agencies with the LEPs has still to be seen and their concomitant effect on attracting and supporting services FDI. A report by (Pike et al., 2013, and the Heseltine Report, 2012) suggests that the tension between national and local actors in attracting Services FDI is still there and that the LEPs are still under-funded. In addition the bureaucratization of the LEPs may harm their agility to help businesses rather to become more bidding and planning orientated. Furthermore the replacement of the RDAs with the LEPs has led to a significant gap due to institutional change which has further hampered their performance (James and Guile, 2014)

The economic and financial difficulties that have beset the UK during the years following the global financial crisis have added importance and urgency to the inward investment policies pursued by the UK's national and regional governments. The UK has remained relatively successful in attracting inbound FDI into the services sector and more generally 
for much of this period, as noted above, resulting in a sustained contribution to economic development in the UK regions. The period since the referendum result in June 2016 has, however seen a substantial decline in the UK's ability to attract and retain FDI of all kinds at both the national and the regional levels, with the maintenance of foreign investment in some sectors, such as financial services being particularly threatened. This worrying situation is now creating new and urgent challenges for inward investment policy makers in both layers of government.

Government policy-makers should possess a clear understanding of the differing influences that attract services FDI to the UK's core and noncore regions. They should place differing degrees of emphasis on the relevance of market, efficiency and strategic asset-enhancing measures, as well as levels of regional support needed to influence MNEs' FDI location decisions (Stone and Peck 1996; Loewendahl 2001b). Government support is also needed to ensure that taxation, investment incentives and exchange rate policies help to create an investment climate conducive to the maximisation of FDI inflows in both types of region.

The search for strategic assets only appears to be a significant motive for FDI location in the core Southeast region. Policies designed to attract competence-creating FDI would therefore seem to have the greatest chance of success in the core regions of the UK, reflecting Cantwell and Mudambi's (2000) argument that investment incentives are likely to be effective in drawing in 'high-technology', R\&D-intensive FDI inflows to the most developed regional economies. 
Policy-makers in the UK's non-core regions would perhaps be better advised to target lower value added FDI, with the potential for higher job-creation (Jones and Wren 2004), given that it is only the South East region that has a strategic asset determinant behind services FDI. They should arguably concentrate on using inward investment policies to promote the diversification of their regional economies, focusing on the creation of sustainable employment in expanding services sectors, rather than additional (but probably short-term) jobs in historically important but (in many cases) contracting manufacturing clusters.

\section{Future research}

Further analysis is needed to explore those factors that attract different types of services FDI (including new and expansionary FDI, wholly owned subsidiaries, joint ventures, greenfield projects, mergers and acquisitions) to the UK's regions. The resultant impacts on economic development and spillovers could also be explored together with the implications for government FDI-related policies.

The attraction of inbound services FDI into different business areas (such as sales and marketing, and leisure) could also be investigated. The findings could be used to revisit Cantwell and Mudambi's (2005) work on subsidiary mandates, and to explore the degree of local embedding of services FDI related projects, along with the resultant employment, cluster, spillover and economic development effects at the regional level.

The net employment effects of inbound services FDI at the UK regional level are still uncertain and thus merit further investigation. Variations in capital intensity between 
regional service FDI projects could also be examined further, as could the importance of MNEs' country of origin to service FDI location.

The future for services is also uncertain as the UK begins its negotiations for its separation from the EU. Access to the single market has been key for many areas of the services sector. A hard Brexit may see UK services lose their competitive advantage and the relocation of service jobs to other EU states. Some service sector will be damaged significantly also by the reduction in any freedom of movement of labour within the EU. It is highly likely that government at both the regional and national level will need to intervene to sustain and attract further service sector FDI. If not, then the fall in services growth will disproportionately affect some regional performance. 


\section{References}

Billington, N. (1999), The Location of Foreign Direct Investment: An Empirical Analysis. Applied Economics, 31(1), 100-120.

Cantwell, J. and Mudambi R. (2000), The Location of MNE R\&D Activity: The Role of Investment Incentives. Management International Review, 40 (Special Issue 1), 127-148.

Cantwell, J. and Mudambi, R. (2005) MNE Competence Creating Subsidiary Mandates. Strategic Management Journal, 26 (12), 1109-1128.

Chakrabarti, A. (2003), A Theory of the Spatial Distribution of Foreign Direct Investment. International Review of Economics and Finance, 12(2), 149- 169.

Cook M and Fallon G (2016), Inward Investment, Employment and Government Polices in Wales. Regional Studies, Policy Debates, 50 (8), 1449-1463.

Crozet, M., T. Mayer and Mucchielli J.L. (2004). How Do Firms Agglomerate? A Study of FDI in France. Regional Science and Urban Economics, 34 (1), 27-54.

Devereux, M.P., R. Griffith and Simpson H. (2001) The Geography of Firm Formation. Institute for Fiscal Studies, London, mimeo.

Driffield, N., S. Lancheros, Y. Temouri and Zhou Y. (2012), Inward FDI in the United Kingdom and its Policy Context. Columbia FDI Profiles, Vale Columbia Center on Sustainable International Investment, Columbia University, 16 July. Available at $\langle$ http://www.vcc.columbia.edu/content/columbia-fdi-profiles $>$.

Driffield, N. and Munday M. (2000), Industrial Performance, Agglomeration and Foreign Manufacturing Investment in the UK. Journal of International Business Studies, 31 (1), $21-37$.

Dunning, J.H. (1981), International Production and Multinational Enterprises, London: 
Harper Collins Publishers.

Dunning, J.H. (1998), Location and the Multinational Enterprise: A Neglected Factor? Journal of International Business Studies, 29 (1), 45-66.

Dunning, J.H. (2005), Global Capitalism, FDI and Competitiveness. Cheltenham: Edward Elgar.

Dunning, J.H. (2006), Towards a New Paradigm of Development: Implications for the Determinants of International Business Activity. Transnational Corporations, 15 (1), 173228.

Dunning, J.H. and Narula R. (1996), The Investment Development Path Revisited: Some Emerging Issues. In: J.H. Dunning and R. Narula, eds., Foreign Direct Investment and Catalysts for Economic Restructuring, pp. 1-42. London: Routledge.

Dunning, J.H. and Narula R. (2004), Multinationals and Industrial Competitiveness. Cheltenham: Edward Elgar.

EY (2017), UK Attractiveness Survey -Time to act, May. Available at:

http://www.ey.com/uk/en/issues/business-environment/ey-uk-attractiveness-survey. Accessed $11^{\text {th }}$ July 2018.

EY (2016), UK Attractiveness Survey - Positive rebalancing? May. Available at: http://www.ey.com/uk/en/issues/business-environment/ey-uk-attractiveness-survey. Accessed 11th July 2018.

Fallon, G. and Cook M. (2010), Exploring the Regional Distribution of Inbound Foreign Direct Investment in the UK in Theory and Practice: Evidence from a Five-Region Study. Regional Studies, 44 (3), 337-353.

Fallon, G., Cook M. and Hall G. (2011), An Analysis of Inbound FDI and its Impact on 
Employment in Wales 1983-2007. UKAIB Conference, Glasgow University, April.

Fallon, G. and Cook M. (2012), An Analysis of EU Inbound FDI and its Impact on Employment in Wales 1983-2009. UK AIB Conference, University of Liverpool, April Fallon, G and Cook, M (2013) The determinants of manufacturing and non-manufacturing FDI in the UK regions. Tijdschrift voor Economische en Sociale Geografie, 105 (3), 331348.

FDI Intelligence (2012), The FDI Report 2012. London: The Financial Times.

Ford, S. and Strange R. (1999), Where Do Japanese Manufacturing Firms Invest within Europe, and Why? Transnational Corporations, 8 (1), 117- 142.

Ghinamo, M., P. Panteghini and Revelli F. (2010), FDI Determination and Corporate Tax Competition in a Volatile World. International Tax and Public Finance, 17 (15), 532-555 Gorg, H. and Ruane F. (2001) Multinational Corporations and Linkages: Panel Data Evidence for the Irish Electronics Sector. International Journal of the Economics of Business, 8 (1), 1-18.

Greene, W.H. (1990), Econometric Analysis, 2nd Edition. London: Prentice Hall. Guimaraes, P., Figueredo O. and Woodward D. (2000) Agglomeration and the Location of Foreign Direct Investment in Portugal. Journal of Urban Studies, 47 (1), 115-135.

Hall, B. H. (2011), The Internationalization of R\&D. UNU-MERIT Working Paper Series 049. United Nations University, Maastricht Economic and Social Research and Training Centre on Innovation and Technology.

Head, K., Ries J. and Swenson D. (1999) Attracting Foreign Manufacturing: Investment Promotion and Agglomeration. Regional Science and Urban Economics, 29 (2), 197-218. Henisz, W.J. and Delios A. (2001), Uncertainty, Imitation, and Plant Location: Japanese 
Multinational Corporations 1990-1996. Administrative Science Quarterly, 46 (3), $443-$ 475.

Heseltine, M. (2012), No Stone Unturned in Pursuit of Growth, DBIS: London Hill, S. and Munday M. (1992), The UK Regional Distribution of Foreign Direct Investment: Analysis and Determinants. Regional Studies, 26 (6), 535- 568.

Hill, S. and Munday M. (1995), Foreign Manufacturing Investment in France and the UK: A Regional Analysis of Locational Determinants. Tijdschrift voor Economische en Sociale Geografie, 86 (4), 311-327.

House of Commons Welsh Affairs Committee (2012). Inward Investment in Wales, 20102012. London.

House of Commons (2015), Powerhouses and engines: Government policy and regional growth inquiry. ttps://www.parliament.uk/business/committees/committees-a-z/commonsselect/business-innovation-and-skills/inquiries/parliament-2015/power-houses-andengines-15-16/ Accessed 1 July 2018.

James, L. and Guile D. (2014), Evaluating the transition from regional development agencies to local Economic Partnerships: the views of SMEs in the British West Midlands. Local Economy, 29 (3), 181-194.

Jones, J. and Wren C. (2004), Inward Foreign Direct Investment and Employment: A Project-based Analysis in North-east England. Journal of Economic Geography, 4 (5), $517-543$.

Jones, J. and Wren C. (2016), Does Service FDI Locate Differently to Manufacturing FDI? A Regional Analysis for Great Britain, Regional Studies, 50 (12), 1980-1994. Judd, C.M. and McClelland G.H. (1989), Data Analysis: A Model-comparison Approach. 
San Diego, CA: Harcourt Brace Jovanovich.

Kottaridi, C. (2005), The Core-periphery Pattern of FDI-led Growth and Production Structure in the EU. Applied Economics 37 (1), 99-113.

Lee, B.-S. and Min B. (2011), Exchange Rates and FDI Strategies of Multinational Enterprises. Pacific Basin Finance Journal, 19 (5), 586-603.

Liebscher, K., Christl, J., Mooslechner P. and Ritzberger-Grünwald, D. eds. (2007), Foreign Direct Investment in Europe. Cheltenham: Edward Elgar.

Loewendahl, H.B. (2001a), Bargaining with Multinationals: The Investment of Siemens and Nissan in North East England. Basingstoke: Palgrave.

Loewendahl, H.B. (2001b) A Framework for FDI Promotion. Transnational Corporations, $10(1), 1-42$.

Mackay, R.R. (2003) Twenty Five Years of Regional Development. Regional Studies, 37 (3), 303-317.

Makino, S., Lau C.-M. and Yeh R.-S. (2005), Asset exploitation versus Asset-seeking: Implications for Location Choice of Foreign Direct Investment from Newly Industrialized Economies. Journal of International Business Studies, 33 (2), 403-422.

Martin, R.L. and Sunley, P. (1996), Paul Krugman's 'Geographical Economics' and Its Implications for Regional Development Theory: A Critical Assessment. Economic Geography, 72 (3), 259-292.

National Assembly for Wales (2014) Inquiry of the Welsh Governments' approach to the promotion of Trade and Inward Investment, Cardiff

Office for National Statistics (2016a), UK Labour productivity, London. Office for National Statistics (ONS) (1981-2015), Regional Trends. London: Office for National Statistics. 
Available at <http:// www.ons.gov.uk>. Accessed 11 July 2018.

Office for National Statistics (ONS) (2016b), Business Monitor MA4: Foreign Direct Investment 20016. London: Office for National Statistics. Available at <http://www.ons.gov.uk>. Accessed 11 July 2018.

Office for National Statistics (ONS) (2010a), Foreign direct investment involving UK companies 2010, Statistical Bulletin. London: Office for National Statistics. Available at <http:// www.ons.gov.uk>. Accessed 11 July 2018.

Office for National Statistics (ONS) (2010b), Business Monitor MA4: Foreign Direct Investment 2009. London: Office for National Statistics. Available at <http://www.ons.gov.uk>. Accessed 11 July 2018.

Office for National Statistics (ONS) (2010c), Information Paper, May, Cardiff, UK.: Office for National Statistics. London: Office for National Statistics. Available at <http://www.ons.gov.uk>. Accessed 11 July 2018.

Office for National Statistics (ONS) (2015), Regional Trends. London: Office for National Statistics. Available at <http://www.ons.gov.uk>. Accessed 11 July 2018.

Office for National Statistics (2017), UK foreign direct investment: trends and analysis: Summer 2017.

https://www.ons.gov.uk/economy/nationalaccounts/balanceofpayments/articles/ ukforeigndirectinvestmenttrendsandanalysis/summer2017. Accessed 3 July 2018. Oxford Economics (2014), Economic Outlook, April. https://www.cityoflondon.gov.uk/business/economic-research-and-information/researchpublications/Documents/economic-outlook-city-of-london-spring-2014.pdf. Accessed 1 July 2018 
Pearce, R. (2006), Globalization and Development: An International Business Strategy Approach. Transnational Corporations, 15 (1), 39-74.

Pike, A., Marlow, D., McCarthy, A., O’Brien, P. and Thomaney J. (2013) Local Institutions and Local Economic Growth: The State of the Local Enterprise Partnerships (LEPs) in England - A National Survey, SERC Discussion paper 150, London school of Economics. Porter, M. (1998), Clusters and the New Economics of Competition: In Theory, Global Markets, Rapid Transportation, and High-speed Communication Should Diminish the Role of Location in Competition. Harvard Business Review, 76 (6), 77-91.

Porter, M. (2000), Location, Competition, and Economic Development: Local Clusters in a Global Economy. Economic Development Quarterly, 14 (1), 15-34.

Raines, P. (2000), Regions in competition: inward investment and regional variation in the use of incentives. Regional Studies, 34(3), 291-296.

Rowthorn, R. (2010), Combined and Uneven Development: Reflections on the North-South Divide. Spatial Economic Analysis, 5(4), 363-388.

Schneider, F. and Frey B.S. (1985), Economic and Political Determinants of Foreign Direct Investment. World Development, 13 (2), 161-175.

Shaver, M.J. and Flyer F. (2000), Agglomeration Economies, Firm Heterogeneity, and Foreign Direct Investment in the United States. Strategic Management Journal, 21 (12), $1175-1193$.

Stone, I. and Peck F. (1996), The Foreign-owned Manufacturing Sector in UK Peripheral Regions 1978-1993: Restructuring and Comparative Performance. Regional Studies, 30 (1), 55-68.

Swamy, P.A., Chang, I.L. Mehta J.S. and Tavlas G.S. (2003), Correcting for Omitted- 
variable and Measurement-error Bias in Autoregressive Model Estimation with Panel Data. Computational Economics, 22 (2-3), 225-253.

Tavares, A.T. and Young S. (2005), FDI and Multinationals: Patterns, Impacts and Policies. International Journal of the Economics of Business, 12 (1), 3-16.

Tewdr-Jones, M. and Phelps D. (2000), Levelling the Uneven Playing Field: Inward Investment, Interregional Rivalry and the Planning System. Regional Studies, 34 (5), 429 440.

The Guardian (2016), What is productivity and why is the UK's so poor, December 2016 Thomas, R and Gunson R. (2017), Scotland Skills 2030 - The future of work and the skills system in Scotland, Institute for Public Policy Research, May

UNCTAD (2017) World Investment Report, Annex tables.

http://unctad.org/en/Pages/DIAE/World\%20Investment\%20Report/Annex-Tables.aspx Accessed: 11 July 2018

UKTI (2011a), The UK Economy at a Glance. UKTI information sheet. Available at <http://www.ukti.gov.uk/>. Accessed 11 July 2018.

UKTI (2011b) , UK Inward Investment Report 2010/11. Available at <http://www.ukti.gov.uk/>. Accessed 11 July 2018.

United Nations Conference on Trade and Development (UNCTAD) (2011), World Investment Report 2011: Non-equity Modes of International Production and Development, New York: United Nations.

United Nations Conference on Trade and Development (UNCTAD) (2012a), World Investment Report 2012: Towards a New Generation of Investment Policies, New York: United Nations. 
United Nations Conference on Trade and Development (UNCTAD) (2012b), Investment Policy Framework for Sustainable Development, New York: United Nations.

Wheeler, D. and Moody A. (1992), International Investment Location Decisions: The Case of US Firms. Journal of International Economics, 33 (1-2), 57-76.

Wilkinson, L. and Dallal G.E. (1981), Tests of Significance in Forward Selection Regression with an F-to-enter Stopping Rule. Technometrics, 23 (4), 377-380.

Wilson, D. and Game, C. (2011), Local government in the United Kingdom. Macmillan International Higher Education.

Wren C. and Jones, J. (2012), FDI Location across British Regions and Agglomerative Forces: A Markov Analysis, Spatial Economic Analysis, 7 (2), 265-286.

Yeung, P. and Strange R. (2005), What Attracts Japanese Manufacturing Investment? Evidence from the United States. UK Academy of International Business, 29th Annual Conference, University of Central Lancashire, 619-631. 
Table 1. Economic Characteristics of sample UK regions (2014-15/16)

\begin{tabular}{|c|c|c|c|c|c|}
\hline $\begin{array}{l}\text { Country and } \\
\text { region }\end{array}$ & $\begin{array}{l}\text { Population } 2015 \\
\text { (thousands) }\end{array}$ & $\begin{array}{l}\text { GVA per } \\
\text { capita index } \\
2015 \\
\text { (£billion) }\end{array}$ & 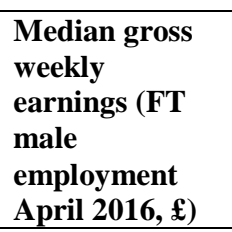 & $\begin{array}{l}\text { Labour Force } \\
2016 \\
\text { (thousands ) }\end{array}$ & $\begin{array}{l}\text { Employment } \\
\text { rate, January } \\
2016(\%)\end{array}$ \\
\hline \multicolumn{6}{|l|}{ Core regions } \\
\hline South East & 8873 & 109.8 & 566.0 & 7159 & 77.9 \\
\hline \multicolumn{6}{|l|}{$\begin{array}{l}\text { Non-core } \\
\text { regions }\end{array}$} \\
\hline $\begin{array}{l}\text { West } \\
\text { midlands }\end{array}$ & 5713 & 82.1 & 510.2 & 2818 & 77.1 \\
\hline North West & 7133 & 86.3 & 503.2 & 3540 & 73.2 \\
\hline Wales & 3113 & 71.0 & 492.4 & 1418 & 71.5 \\
\hline Scotland & 5404 & 93.4 & 535.0 & 2733 & 74.5 \\
\hline $\begin{array}{l}\text { Country and } \\
\text { Region }\end{array}$ & $\begin{array}{l}\text { Unemployment } \\
\text { rate spring } 2016\end{array}$ & $\begin{array}{l}\% \text { pupils } \\
\text { achieving } 5 \text { or } \\
\text { more GCSE } \\
\text { grades A*-C, } \\
2014-15\end{array}$ & $\begin{array}{l}\text { Proportion of } 16 \\
\text { year olds in post } \\
\text { compulsory } \\
\text { education and } \\
\text { government } \\
\text { training schemes } \\
(2014-15)\end{array}$ & $\begin{array}{l}\text { R\&D } \\
\text { expenditure all } \\
\text { sectors } 2015 \\
(£ \mathrm{~m})\end{array}$ & $\begin{array}{l}\text { Regional Aid } \\
(£ \mathrm{~m})\end{array}$ \\
\hline \multicolumn{6}{|l|}{ Core regions } \\
\hline South East & 4.0 & 70.9 & 90.0 & 6527 & 0.3 \\
\hline \multicolumn{6}{|l|}{$\begin{array}{l}\text { Non-core } \\
\text { regions }\end{array}$} \\
\hline $\begin{array}{l}\text { West } \\
\text { midlands }\end{array}$ & 5.6 & 66.9 & 88.0 & 2470 & 3 \\
\hline North West & 5.3 & 68.6 & 87.0 & 2903 & 28 \\
\hline Wales & 4.4 & 64.3 & 89.5 & 663 & 137 \\
\hline Scotland & 5.1 & 78.1 & 88.0 & 2222 & 140 \\
\hline
\end{tabular}

Source: ONS (1981-2016); http://www.statistics.gov.uk/downloada/Regional_Trends. 
Table 2. Regional services output and share of regional non-primary output, (1980-2015).

\begin{tabular}{|c|c|c|c|c|c|}
\hline Region & 1980 & 1990 & 2000 & 2010 & 2015 \\
\hline \multicolumn{6}{|l|}{ Core } \\
\hline Southeast & $\begin{array}{l}34,206 \\
(79 \%)\end{array}$ & $\begin{array}{l}75,726 \\
(80 \%)\end{array}$ & $\begin{array}{l}110,852 \\
(86 \%)\end{array}$ & $\begin{array}{l}193,259 \\
(90 \%)\end{array}$ & $\begin{array}{l}228,296 \\
(90 \%)\end{array}$ \\
\hline \multicolumn{6}{|l|}{ Non-core } \\
\hline West Midlands & $\begin{array}{l}10,090 \\
(64 \%)\end{array}$ & $\begin{array}{l}25,555 \\
(67 \%)\end{array}$ & $\begin{array}{l}49,736 \\
(75 \%)\end{array}$ & $\begin{array}{l}873,15 \\
(86 \%)\end{array}$ & $\begin{array}{l}100,806 \\
(87 \%)\end{array}$ \\
\hline Northwest & $\begin{array}{l}13,541 \\
(67 \%)\end{array}$ & $\begin{array}{l}31,547 \\
(70 \%)\end{array}$ & $\begin{array}{l}63,106 \\
(77 \%)\end{array}$ & $\begin{array}{l}115,312 \\
(84.5 \%)\end{array}$ & $\begin{array}{l}131,898 \\
(85 \%)\end{array}$ \\
\hline Wales & $\begin{array}{l}5,451 \\
(73 \%)\end{array}$ & $\begin{array}{l}13,070 \\
(70 \%)\end{array}$ & $\begin{array}{l}23,049 \\
(75 \%)\end{array}$ & $\begin{array}{l}40,048 \\
(84.4 \%)\end{array}$ & $\begin{array}{l}46,319 \\
(84 \%)\end{array}$ \\
\hline Scotland & $\begin{array}{l}11,710 \\
(75 \%)\end{array}$ & $\begin{array}{l}27,480 \\
(77 \%)\end{array}$ & $\begin{array}{l}51,799 \\
(81 \%)\end{array}$ & $\begin{array}{l}91,950 \\
(84.5 \%)\end{array}$ & $\begin{array}{l}109,395 \\
(89 \%)\end{array}$ \\
\hline
\end{tabular}

Sources : ONS (1981-2016); http://www.statistics.gov.uk/downloada/Regional_Trends. 
Table 3. Regional distribution of new UK Services FDI projects and percentage of overall regional new projects (1980-2015).

\begin{tabular}{llllll}
\hline Region & $\mathbf{1 9 8 0}$ & $\mathbf{1 9 9 0}$ & $\mathbf{2 0 0 0}$ & $\mathbf{2 0 1 0}$ & $\mathbf{2 0 1 5}$ \\
\hline Core & & & & & \\
Southeast & $9(56 \%)$ & $13(62 \%)$ & $167(87 \%)$ & $114(75 \%)$ & $50(69.4 \%)$ \\
Non-core & & & & & \\
West Midlands & $1(33 \%)$ & $24(30 \%)$ & $56(54 \%)$ & $46(59 \%)$ & $66(60 \%)$ \\
Northwest & $4(15 \%)$ & $14(20 \%)$ & $28(72 \%)$ & $119(68 \%)$ & $63(64 \%)$ \\
Wales & $2(12 \%)$ & $8(11 \%)$ & $13(33 \%)$ & $22(58 \%)$ & $26(63 \%)$ \\
Scotland & $6(19 \%)$ & $8(20 \%)$ & $40(56 \%)$ & $68(70 \%)$ & $76(63 \%)$ \\
& & & & & \\
\hline
\end{tabular}

Sources : ONS (1981-20016); http://www.statistics.gov.uk/downloada/Regional_Trends. 
Table 4. Explanatory variables used to measure market-seeking FDI.

\begin{tabular}{|c|c|c|c|}
\hline Influences on FDI & Related variables & Expected sign & Unit of Analysis \\
\hline $\begin{array}{l}\text { Residentregional population (all } \\
\text { persons) }\end{array}$ & REGPOPN & Positive & Thousands \\
\hline Gross regional GDP & REGGDPGRS & Positive & Thousands \\
\hline Gross regional GDP (real terms) & REGGDPREAL & Positive & Thousands \\
\hline RegionalGDP percapita & REGGDPPC & Positive & \\
\hline \multicolumn{4}{|l|}{ Thousands } \\
\hline $\begin{array}{l}\text { Real regional GDP per capita (real } \\
\text { terms) }\end{array}$ & REGGDPPCREAL & Positive & Thousands \\
\hline $\begin{array}{l}\text { Regionalexpenditure onroads (annual } \\
\text { basis) }\end{array}$ & REGROAD & Positive & Thousands \\
\hline Ratio length highways to land area & REGINFRA & Positive & Kilometres per hectare \\
\hline $\begin{array}{l}\text { Direct inward investment new projects } \\
\text { (regional level) }\end{array}$ & REGFOLLOW & Positive & Number \\
\hline $\begin{array}{l}\text { One yearlag of directinward investment new } \\
\text { projects at a regional level }\end{array}$ & REGINERTIA & Positive & $\begin{array}{l}\text { Number lagged by one } \\
\text { year }\end{array}$ \\
\hline $\begin{array}{l}\text { One year lag of direct inward investment in new } \\
\text { services projects at a regional level }\end{array}$ & REGINON & Positive & $\begin{array}{l}\text { Number lagged by one } \\
\text { year }\end{array}$ \\
\hline $\begin{array}{l}\text { Regionalexpenditure on roads (annual basis, } \\
\text { realterms) }\end{array}$ & REGROADREAL & Positive & Thousands \\
\hline Resident UK population (all persons) & UKPOPN & Positive & Thousands \\
\hline Gross UKGDP & UKGDP & Positive & Hundreds of millions \\
\hline Gross UK GDP (real terms) & UKGDPREAL & Positive & Hundreds of millions \\
\hline UKGDP per capita & UKGDPPC & Positive & Pounds \\
\hline Real UK GDP percapita & UKGDPPCREAL & Positive & Pounds \\
\hline $\begin{array}{l}\text { UKexpenditure on roads (annual, } \\
\text { England proxy) }\end{array}$ & UKROAD & Positive & Thousands \\
\hline Ratio length highways to land area & UKINFRA & Positive & Kilometres per hectare \\
\hline $\begin{array}{l}\text { RealUKexpenditure on roads (annual basis, } \\
\text { England proxy) }\end{array}$ & UKROAD REAL & Positive & Thousands \\
\hline $\begin{array}{l}\text { Direct inward investment new projects } \\
\text { (national level) }\end{array}$ & UKFOLLOW & Positive & Number \\
\hline $\begin{array}{l}\text { One yearlag of directinward investment new } \\
\text { projectsatanationallevel }\end{array}$ & UKINERTIA & Positive & Number \\
\hline GDP,EU 15 & EUGDP & Positive & Millions \\
\hline
\end{tabular}

Sources: Regional trends, DTI transport statistics, UK national statistics. 
Table 5 -Explanatory variables used to measure efficiency-seeking FDI.

\section{Influences on FDI}

Expected sign

Unit of Analysis

Total regional labour force (thousands)

Regional claimant unemployment (count rates) REGCLUNEMP

School leavers' examination achievements by gender-pupils achieving 5 or more grades at GCSE A*-C ${ }^{\mathrm{a}}$

Percentage of 16 year olds in education and government supported training schemes

Average wage costs per manual employee

Average wage costs per manual employee (real terms)

Average weeklyearnings(regionalmale wages) / national average

Regional outputperemployee

Year-on-year change in output peremployee (year 2-year 1)

Working days lost per 1,000 employees through labour disputes

Ratio of numbers in employment toland area

Share of top 4 clusters in regional GDP a

Net annual change in small business registrations

Total national labourforce (thousands)

UKclaimantunemployment (countrates)

School leavers' examination achievements by gender-pupils achieving 5 or more grades at GCSE A*-C

Percentage of 16 year olds in education and government supported training schemes ${ }^{\mathrm{a}}$

Average wage costs per manual employee

Average wage costs per manual employee (real terms)

Average weeklyearnings(nationalmale wages) / national average

National outputperemployee

Year-on-year change in output peremployee (year 2-year 1)

Working days lost per 1,000 employees through labour disputes

Ratio of numbers in employment to land area

Share of top 4 clusters in UK GDP ${ }^{a}$

Net annual change in small business registrations
REGEMPLOY

Positive

Positive/Negative

Positive

REGBASICED

REGEDU

Positive

Percentage

REGAWC

REGAWCREAL

Negativeorpositive

Negative

REGWAGINEQ

Negative

REGPRODUCTI

REGCHANGEPROD

Positive

Positive

REGDISPUTES

REGAGGLOM

REGCLUSTERS

REGBUSREG

UKEMPLOY

UKCLUNEMP

UKBASICED

UKEDU

UKAWCREAL

UKWAGINEQ

UKPRODUCTI

Negative

Positive

Positive

Positive

Positive

Positive/Negative

Positive

Positive

Negative/positive

Negative

Negative

Positive

Positive

UKCHPROD

UKDISPUTES

UKAGGLOM

UKCLUSTERS

UKBUSREG
Negative

Positive

Positive

Positive
UKAWC
Percentage

Ratio

Ratio

Ratio

Thousands

Hundreds

Hundreds

Ratio

Millions

Number

Ratio

Ratio

Percentage

Number

thousands

Thousands

Thousands

pounds

Thousands

Hundreds

Ratio

Percentage

Number,

hundreds
Percentage

Note : ${ }^{\mathrm{a}}$ Also potential influences on strategic asset-seeking FDI inflows.

Sources : Regional trends, DTI transport statistics, UK national statistics. 
Table 6- Explanatory variables used to measure strategic asset-seeking FDI.

\section{Influences on FDI} business plus government plus HEIs)

Share of top 4 clusters in regional GDPa

Percentage of 16 yearolds ineducation and government supported training schemes ${ }^{\text {a }}$

Total UK expenditure on $R \& D$

Total UK expenditure on R\&D (real terms)

Share of top 4 clusters in UK GDP ${ }^{\mathrm{a}}$

Percentage of 16 year olds in education and government supported training schemes ${ }^{\text {a }}$
Total regional expenditure on $\mathrm{R} \& \mathrm{D}$ (£million,

Total regional expenditure on $\mathrm{R} \& \mathrm{D}$ (real terms)

\section{Related variables Expected sign Unit of Analysis}

\begin{tabular}{|c|c|c|}
\hline REGRAND & Positive & Millions \\
\hline REGRANDREAL & Positive & Millions \\
\hline REGCLUSTERS & Positive & Percentage \\
\hline REGEDU & Positive & Percentage \\
\hline UKRAND & Positive & Millions \\
\hline UKRANDREAL & Positive & Millions \\
\hline UKCLUSTERS & Positive & Percentage \\
\hline UKEDU & Positive & Percentage \\
\hline
\end{tabular}

Note: ${ }^{\mathrm{a}}$ Also

potentialinfluences

onefficiency-

seeking FDIinflows.

Sources : Regional

Trends, DTI transport

statistics, UK national

statistics. 
Table7. Explanatory variables used to measure influence of government policy on FDI.

\begin{tabular}{|c|c|c|c|}
\hline Influences on FDI & Related Variables & Expected Sign & Unit of Analysis \\
\hline $\begin{array}{l}\text { Government spending on } \\
\text { regional financial } \\
\text { assistance to business }\end{array}$ & REGFIN & Positive & Millions \\
\hline $\begin{array}{l}\text { Government spending on } \\
\text { regional financial } \\
\text { assistance to business (real } \\
\text { terms) }\end{array}$ & REGFINREAL & Positive & Millions \\
\hline UK Corporation tax rates & UKTAX & Negative & Percentage \\
\hline $\begin{array}{l}\text { Sterling/US Dollar } \\
\text { exchange rates }\end{array}$ & $£ \$ E X C H R A T E$ & Negative & Ratio of Pound/US Dollar \\
\hline $\begin{array}{l}\text { Dummy variable(English } \\
\text { regions, RDAs) }\end{array}$ & D1 & Positive & $\begin{array}{l}\text { Dummy variable, takes } \\
\text { the value zero before the } \\
\text { setting up of the regional } \\
\text { development agencies, } \\
\text { one thereafter until their } \\
\text { demise (2010) }\end{array}$ \\
\hline Dummy variable (LEPs) & $\mathrm{D} 2$ & Positive & $\begin{array}{l}\text { Dummy variable takes } \\
\text { the value zero until 2011, } \\
\text { then } 1 \text { thereafter }\end{array}$ \\
\hline $\begin{array}{l}\text { Dummy variable(non- } \\
\text { English devolution) }\end{array}$ & D3 & Positive & $\begin{array}{l}\text { Takes the value zero } \\
\text { before setting up of } \\
\text { national assemblies in } \\
1999 \text { and } 1 \text { thereafter }\end{array}$ \\
\hline $\begin{array}{l}\text { Dummy } \\
\text { Variable(Financial crisis) }\end{array}$ & $\mathrm{D} 4$ & Negative & $\begin{array}{l}\text { Takes the value zero until } \\
2007,1 \text { from } 2008-2011 \text {, } \\
\text { then zero thereafter. }\end{array}$ \\
\hline
\end{tabular}

Sources: Regional Trends, UK national statistics, various issues. 
Table 8 - Multiple Regression results (Significant independent variables)

\begin{tabular}{|c|c|c|c|c|c|}
\hline & $\begin{array}{l}\text { South East } \\
\text { Service Sector }\end{array}$ & $\begin{array}{l}\text { West Midlands } \\
\text { service sector }\end{array}$ & $\begin{array}{l}\text { Wales Service } \\
\text { Sector }\end{array}$ & $\begin{array}{l}\text { Scotland Service } \\
\text { sector }\end{array}$ & $\begin{array}{l}\text { North West } \\
\text { Service sector }\end{array}$ \\
\hline \multicolumn{6}{|l|}{$\begin{array}{l}\text { Market seeking } \\
\text { FDI }\end{array}$} \\
\hline $\begin{array}{l}\text { Real regional GDP } \\
\text { per capita (real } \\
\text { terms) }\end{array}$ & $\begin{array}{l}(0.060) \\
\text { REGGDPCR } \\
*(+\mathrm{ve}) \\
0.000\end{array}$ & & & & \\
\hline $\begin{array}{l}\text { One year lagged } \\
\text { regional FDI }\end{array}$ & $\begin{array}{l}(0.008) \\
\text { REGINON } \\
*(+\mathrm{ve}) \\
0.000 \\
\end{array}$ & & & & \\
\hline $\begin{array}{l}\text { National follow- } \\
\text { my leader FDI }\end{array}$ & & $\begin{array}{l}(0.006) \\
\text { UKFOLLOW } \\
*(+\mathrm{ve}) \\
0.000\end{array}$ & & & \\
\hline $\begin{array}{l}\text { Real UKGDP per } \\
\text { capita }\end{array}$ & & & & $\begin{array}{l}(0.083) \\
\text { UKGDPPCR } \\
*(+\mathrm{ve}) \\
0.000\end{array}$ & \\
\hline \multicolumn{6}{|l|}{$\begin{array}{l}\text { Efficiency } \\
\text { Seeking FDI }\end{array}$} \\
\hline $\begin{array}{l}\text { Real average } \\
\text { weekly earnings }\end{array}$ & & & & $\begin{array}{l}(12.870) \\
\text { REGWAGINEQ } \\
*(+\mathrm{ve}) \\
0.000 \\
\end{array}$ & \\
\hline $\begin{array}{l}\text { Share of top four } \\
\text { clusters in regional } \\
\text { GDP }\end{array}$ & $\begin{array}{l}(0.18) \\
\text { REGCLUSTERS } \\
*(+v e) \\
0.000\end{array}$ & & & & \\
\hline $\begin{array}{l}\text { Regional Real } \\
\text { average wage } \\
\text { costs per manual } \\
\text { employee } \\
\end{array}$ & $\begin{array}{l}(-3.872) \\
\text { REGAWCREAL } \\
*(-\mathrm{ve}) \\
0.000 \\
\end{array}$ & & & & \\
\hline $\begin{array}{l}\text { Regional pupils } \\
\text { achieving } 5 \text { or } \\
\text { more pass grades } \\
\text { at GCSE }\end{array}$ & & & & & $\begin{array}{l}(-0.042) \\
\text { REGBASICED } \\
* *(-\mathrm{ve}) \\
0.030 \\
\end{array}$ \\
\hline $\begin{array}{l}\text { Regional claimant } \\
\text { unemployment }\end{array}$ & & & $\begin{array}{l}(-0.093) \\
\text { REGCLUNEMP } \\
*(-\mathrm{ve}) \\
0.006 \\
\end{array}$ & & \\
\hline $\begin{array}{l}\text { Regional output } \\
\text { per employee }\end{array}$ & & & & & $\begin{array}{l}(0.328) \\
\text { REGPRODUCTI } \\
*(+\mathrm{ve}) \\
0.000 \\
\end{array}$ \\
\hline \multicolumn{6}{|l|}{$\begin{array}{l}\text { Strategic asset } \\
\text { seeking FDI }\end{array}$} \\
\hline $\begin{array}{l}\text { Share of top four } \\
\text { clusters in regional } \\
\text { GDP }\end{array}$ & $\begin{array}{l}(0.18) \\
\text { REGCLUSTERS } \\
*(+\mathrm{ve}) \\
0.000\end{array}$ & & & & \\
\hline \multicolumn{6}{|l|}{$\begin{array}{l}\text { Government } \\
\text { Policy }\end{array}$} \\
\hline $\begin{array}{l}\text { Government } \\
\text { spending on } \\
\text { regional assistance } \\
\text { in real terms }\end{array}$ & & $\begin{array}{l}(3.518) \\
\text { REGFINREAL } \\
*(+\mathrm{ve}) \\
0.000 \\
\end{array}$ & $\begin{array}{l}(-0.721) \\
\text { REGFINREAL } \\
*(-\mathrm{ve}) \\
0.004 \\
\end{array}$ & & \\
\hline $\begin{array}{l}\text { Dummy Variable } \\
\text { (non-English } \\
\text { Devolution) }\end{array}$ & & & & $\begin{array}{l}(0.562) \\
\text { D3 } \\
*(+\mathrm{ve}) \\
0.004\end{array}$ & \\
\hline $\begin{array}{l}\text { Financial Crisis } \\
\text { Dummy variable }\end{array}$ & $\begin{array}{l}(-0.410) \\
\text { D4 }\end{array}$ & & $\begin{array}{l}(-0.231) \\
\text { D4 }\end{array}$ & & \\
\hline
\end{tabular}




\begin{tabular}{|l|l|l|l|l|l|}
\hline (D4) & $*(-\mathrm{ve})$ & $* *(-\mathrm{ve})$ & & \\
& 0.000 & 0.007 & & \\
\hline
\end{tabular}

Notes: statistically significant $*(0.001) * *(0.05)$ levels. Foreign direct investment, GDP grosses domestic product, +ve positive -ve negative

Coefficients are in brackets. Significance level listed under each variable based upon White's standard error

Source: Estimated from authors' findings 